\title{
Low temperatures enhance organic nitrate formation: evidence from observations in the 2012 Uintah Basin Winter Ozone Study
}

\author{
L. Lee ${ }^{1}$, P. J. Wooldridge ${ }^{1}$, J. B. Gilman ${ }^{2}$, C. Warneke ${ }^{2}$, J. de Gouw ${ }^{2}$, and R. C. Cohen ${ }^{1,3}$ \\ ${ }^{1}$ Department of Chemistry, University of California, Berkeley, CA, USA \\ ${ }^{2}$ Chemical Science Division, Earth System Research Laboratory, National Oceanic \& Atmospheric Administration, \\ Boulder, CO, USA \\ ${ }^{3}$ Department of Earth and Planetary Sciences, University of California, Berkeley, CA, USA
}

Correspondence to: R. C. Cohen (rccohen@ berkeley.edu)

Received: 28 May 2014 - Published in Atmos. Chem. Phys. Discuss.: 30 June 2014

Revised: 23 September 2014 - Accepted: 10 October 2014 - Published: 27 November 2014

\begin{abstract}
Nitrogen dioxide $\left(\mathrm{NO}_{2}\right)$ and total alkyl nitrates ( $\Sigma$ ANs) were measured using thermal dissociation laserinduced fluorescence during the 2012 Uintah Basin Winter Ozone Study (UBWOS) in Utah, USA. The observed $\mathrm{NO}_{2}$ concentration was highest before sunrise and lowest in the late afternoon, suggestive of a persistent local source of $\mathrm{NO}_{2}$ coupled with turbulent mixing out of the boundary layer. In contrast, $\Sigma$ ANs co-varied with solar radiation with a noontime maximum, indicating that local photochemical production combined with rapid mixing and/or deposition was the dominant factor in determining the $\Sigma$ AN concentrations. We calculate that $\Sigma$ ANs were a large fraction $(\sim 60 \%)$ of the $\mathrm{HO}_{\mathrm{x}}$ free radical chain termination and show that the temperature dependence of the alkyl nitrate yields enhances the role of $\Sigma$ ANs in local chemistry during winter by comparison to what would occur in the warmer temperatures of summer.
\end{abstract}

\section{Introduction}

The Uintah Basin in Utah is a region of concentrated fossil fuel extraction operations using hydraulic fracturing to extract natural gas and oil from shale formations. The basin has experienced high wintertime ozone, as has the nearby Upper Green River Basin in Wyoming (Schnell et al., 2009). The observed $\sim 200 \mathrm{ppb}$ peak ozone in the basin during the winter of 2011 was associated with elevated concentrations of volatile organic compounds (VOCs) coincident with a shallow boundary layer stabilized by snow cover, which doubled as a solar reflector leading to more rapid photochemistry.
Organic nitrates $\left(\mathrm{RONO}_{2}\right)$ are products of atmospheric VOC oxidation in the presence of $\mathrm{NO}_{\mathrm{x}}\left(\mathrm{NO}+\mathrm{NO}_{2}\right)$. During daytime, their formation involves the association reaction of alkyl peroxy radicals with NO. This reaction terminates ozone formation and suppresses $\mathrm{OH}$ recycling. The importance of $\mathrm{RONO}_{2}$ formation as an $\mathrm{NO}_{\mathrm{x}}$ sink and chain terminator of ozone production depends on the mixture of VOCs present as a result of variations in $\mathrm{OH}$ reactivity and organic nitrate yield, $\alpha$, among different organic molecules (Perring et al., 2013; Farmer et al., 2011). Laboratory studies have shown that the nitrate yield follows standard expectations for three-body reactions: $\alpha$ increases with the carbon number of the organic peroxy radical and atmospheric pressure, but decreases with temperature (Atkinson et al., 1983; Carter and Atkinson, 1989). Field observations have found $\mathrm{RONO}_{2}$ compounds to account for $25 \%$ or more of total reactive nitrogen $\left(\mathrm{NO}_{\mathrm{y}}\right.$, defined as $\mathrm{NO}_{\mathrm{x}}+$ higher nitrogen oxides). However, none of these prior field experiments (Farmer et al., 2011; Rosen et al., 2004; Perring et al., 2009, 2010) covered a temperature range wide enough to examine the role of the temperature dependence of $\alpha$ on nitrate formation rates, $\mathrm{O}_{3}$ levels, or $\mathrm{OH}$ concentrations.

In this paper we present observations of organic nitrates obtained during the the 2012 Uintah Basin Winter Ozone Study (UBWOS) experiment (15 January-29 February 2012). We further describe the role of organic nitrates in wintertime ozone production and the associated temperature effect by comparing the $\alpha$ values either constrained by observed total alkyl nitrates ( $\Sigma$ ANs) concentration or derived from temperature-dependent yields from VOC compo- 

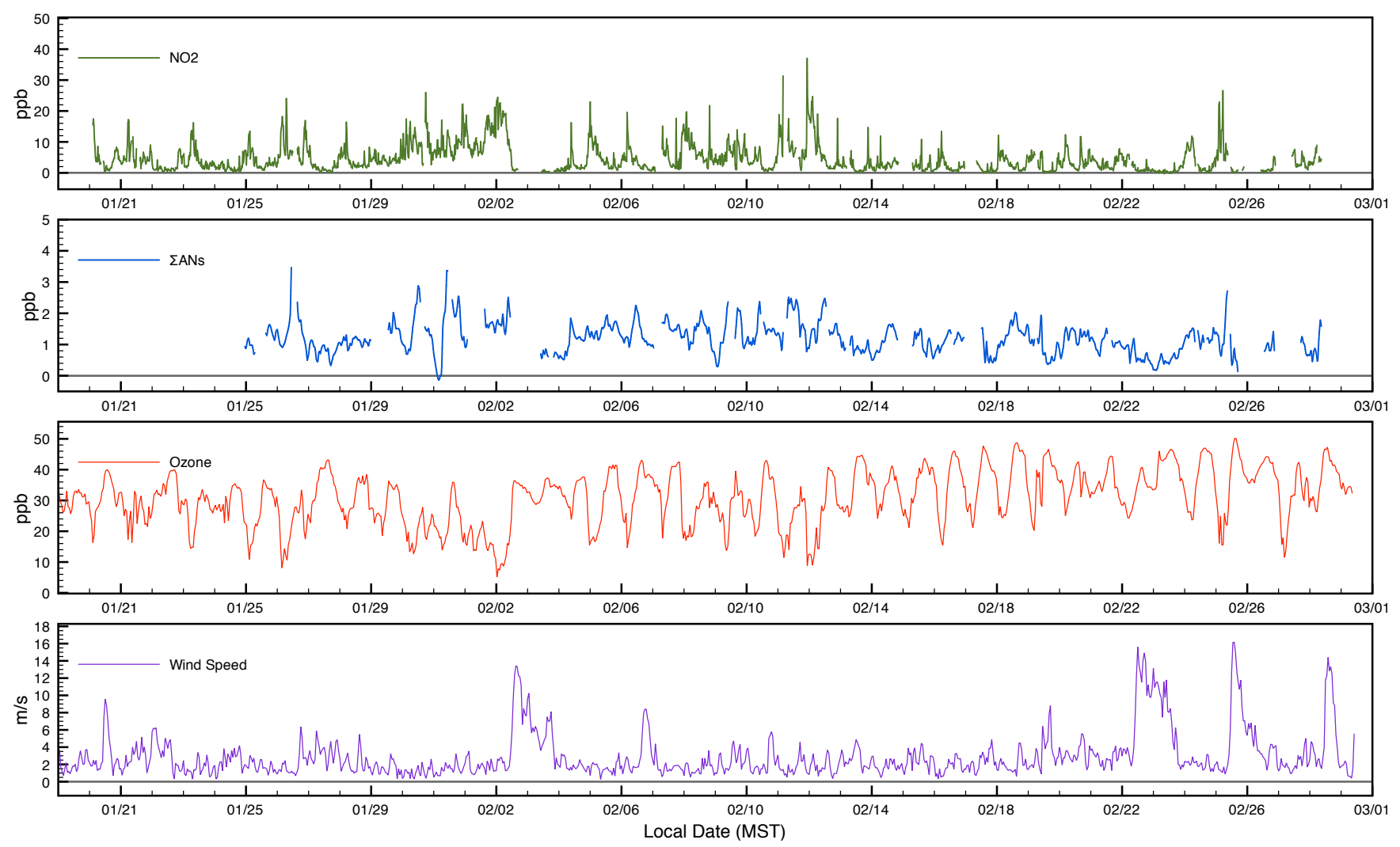

Figure 1. Hourly-averaged time series of $\mathrm{NO}_{2}$, total alkyl nitrates ( $\left.\Sigma \mathrm{ANs}\right), \mathrm{O}_{3}$, and wind speed measured during UBWOS 2012. The concentrations are measured at a height of $16 \mathrm{~m}$ from a $19 \mathrm{~m}$ scaffolding tower on site. The wind speed is measured at the tower's top. Ticks on the $x$ axis mark local midnight.

sition data. The findings show organic nitrate formation to be one of the primary radical sinks at this site and confirm that the temperature-dependent kinetics are important. However, temperature dependence of organic nitrate yields are not presented in any of the standard photochemical mechanisms used in chemical transport models. Accounting for the temperature-dependent yields at $0{ }^{\circ} \mathrm{C}$ (the typical daytime temperature during this field campaign) results in a $30 \%$ faster organic nitrate formation rate than what would occur at room temperature $(300 \mathrm{~K})$. As a result, we estimate a suppression in $\mathrm{OH}$ concentrations by $15 \%$ and ozone formation by $20 \%$ relative to calculations that do not include the temperature dependence of the $\mathrm{RONO}_{2}$ yields.

\section{Instrumentation}

UBWOS 2012 was conducted from 15 January to the end of February at Horse Pool, Utah, a site approximately $30 \mathrm{mi}$ south of the city of Vernal, Utah. This site was located amid intensive oil and gas extraction operations near the center of Uintah Basin, with dense gas production wells to the south and oil production wells to the southwest (refer to Fig. 1 of
Edwards et al., 2013). A $19 \mathrm{~m}$ high tower was located on site for setting up measurements at various heights.

Thermal Dissociation-Laser Induced Fluorescence (TD-LIF) was used to measure $\mathrm{NO}_{2}$, total peroxy nitrates $\left(\Sigma \mathrm{PNs}=\Sigma \mathrm{ROONO}_{2}\right)$, and total alkyl nitrates $\left(\Sigma \mathrm{ANs}=\Sigma \mathrm{RONO}_{2}\right)$ using methods described previously (Day et al., 2002; Thornton et al., 2000). Briefly, laserinduced fluorescence was used for detection of gas-phase $\mathrm{NO}_{2}$ using a pulsed tunable fiber laser $(\sim 80 \mathrm{~mW}$, NovaWave) at $530 \mathrm{~nm}$ for excitation with detection of photons at wavelengths longer than $700 \mathrm{~nm}$ using a red-sensitive photomultiplier tube (PMT; Hamamatsu H7421) preceded by a dielectric long-pass filter. Quartz tubes with external heating elements were maintained at $180^{\circ} \mathrm{C}$ for conversion of $\Sigma$ PNs and $380^{\circ} \mathrm{C}$ for $\Sigma$ ANs to $\mathrm{NO}_{2}$ under a residence time of $\sim 0.17 \mathrm{~s}$. The air samples passing through the heated regions were under near ambient atmospheric pressure before entering a restrictive orifice into a low-pressure transfer line to the LIF cell. Simultaneous measurements of $\mathrm{NO}_{2}, \Sigma$ PNs, and $\Sigma$ ANs were achieved by operating three LIF cells, each measuring the cumulative concentration of $\mathrm{NO}_{2}$-yielding compounds.

Laboratory experiments carried out after the deployment indicate that the $\Sigma$ ANs channel had been set to a tempera- 
ture that was higher than necessary to fully dissociate alkyl nitrates. The $\mathrm{O}_{3}$ pyrolysis and subsequent $\mathrm{O}$ atom-initiated chemistry, usually a very minor negative interference (Day et al., 2002), resulted in a large enough effect to require a correction term for this data set. The correction is an empirical relationship developed in the laboratory by directly observing the loss of the $380^{\circ} \mathrm{C}$ signal as a function of both $\mathrm{O}_{3}$ and $\mathrm{NO}_{2}$ concentrations in the presence of an organic nitrate surrogate (2-ethylhexyl nitrate, Sigma-Aldrich). Details of this correction are included in Appendix A. The factors applied during the daytime hours that are the focus of this study were typically $6-17 \%$ of the total $380{ }^{\circ} \mathrm{C}$ signal, of which $\Sigma$ ANs account for approximately $25 \%$. This amounts to a correction of $24-68 \%$ of the final $\Sigma$ ANs concentration. Larger corrections were required at night due to higher $\mathrm{NO}_{2}$ concentration. There are also additional contributions from inorganic species, including $\mathrm{N}_{2} \mathrm{O}_{5}$ (which decomposes to $\mathrm{NO}_{2}$ and $\mathrm{NO}_{3}$ at $\sim 90^{\circ} \mathrm{C}$ ) in the $180^{\circ} \mathrm{C}$ channel and $\mathrm{ClNO}_{2}$ (which decomposes to a chlorine atom and $\mathrm{NO}_{2}$, Thaler et al., 2011) in the $380^{\circ} \mathrm{C}$ channel. However, accounting for the inorganic signal was straightforward since direct measurements of both species were available at the site (Wagner et al., 2011; Roberts et al., 2009). Overall, the $\mathrm{ClNO}_{2}$ contribution to the signal difference between $380^{\circ} \mathrm{C}$ and $180^{\circ} \mathrm{C}$ was only significant during the night and early morning since, for example, the noontime photolysis lifetime of $\mathrm{ClNO}_{2}$ is only $1 \mathrm{~h}$. We note that $\mathrm{N}_{2} \mathrm{O}_{5}$, present only at night, did not affect daytime $\Sigma$ PNs measurements.

In subsequent analyses, $\Sigma$ PNs is calculated as the difference in concentrations of the ambient and $180^{\circ} \mathrm{C}$ channel minus the $\mathrm{N}_{2} \mathrm{O}_{5}$ contribution, while $\Sigma$ ANs is calculated as the concentration difference between the $180^{\circ} \mathrm{C}$ channel and the $\mathrm{O}_{3}$-corrected $380^{\circ} \mathrm{C}$ channel minus the $\mathrm{ClNO}_{2}$ contribution.

The TD-LIF instrument was calibrated hourly with a 5 ppm $\mathrm{NO}_{2}$ gas standard diluted with zero air to generate five different concentration levels at the inlet manifold. In addition, the instrument zero (baseline) was monitored every half-hour by overflowing the inlet with $\mathrm{NO}_{\mathrm{x}}$-free zero air. The $\mathrm{NO}_{2}$ concentration measured by LIF and nearby chemiluminescence instrument were within $7 \%$ of each other on average, giving a linear slope (LIF vs. chemiluminescence) of 0.94 , an intercept of $0.02 \mathrm{ppb}$, and an $R^{2}$ value of 0.97 .

The inlet was mounted on the southern face of the tower, $16 \mathrm{~m}$ above the ground. Other measurements made from similar heights include $\mathrm{NO}$ and $\mathrm{NO}_{\mathrm{y}}$ (Kliner et al., 1997), speciated VOCs (Goldan et al., 2004), $\mathrm{O}_{3}$, and photolysis rates for $\mathrm{O}_{3}\left(\mathrm{O}^{1} \mathrm{D}\right), \mathrm{NO}_{2}$, and $\mathrm{NO}_{3}$. These measurements are described elsewhere (see description and Table S1 of the Supplement in Edwards et al., 2013). Temperature, pressure, relative humidity, wind direction, and wind speed were measured from the top of the tower. Three-dimensional wind data were measured using the high-resolution Doppler lidar (Grund et al., 2001) nearby.

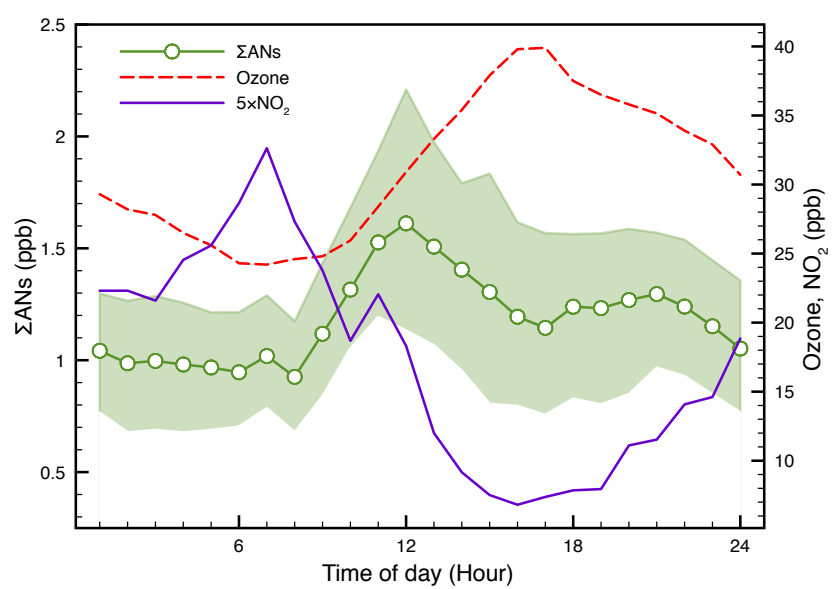

Figure 2. Diurnal variations of $\Sigma \mathrm{ANs}$, ozone, and $\mathrm{NO}_{2}$. Lines represent median values while the shaded area of $\Sigma$ ANs represents the interquartile (25-75\%) coverage. The $\Sigma \mathrm{AN}$ data have been corrected for $\mathrm{O}_{3}$ interference and the $\mathrm{ClNO}_{2}$ contribution has been subtracted (see text).

\section{Results}

\subsection{Observations}

Figure 1 shows the time series (as hourly average) of $\mathrm{NO}_{2}$, $\Sigma$ ANs, $\mathrm{O}_{3}$, and wind speed through the observational period. The time-of-day median values of $\mathrm{NO}_{2}, \Sigma \mathrm{ANs}$, and $\mathrm{O}_{3}$ are plotted in Fig. 2. During periods with wind speed lower than $5 \mathrm{~m} \mathrm{~s}^{-1}$, chemical species such as large volatile organic compounds (VOCs) and $\mathrm{NO}_{\mathrm{x}}$, accumulate, leading to an increase in concentrations until high wind episodes occur that flush the basin with clean air. The onset of high wind episodes was therefore coincident with a rapid decrease in concentrations of VOCs and $\mathrm{NO}_{\mathrm{x}}$. During the UBWOS campaign in 2011, up to $200 \mathrm{ppb}$ ozone was observed at the end of accumulation periods with snow cover on the ground. However, during a similar period in the 2012 campaign, there was little snow and the ozone concentration did not exceed $51 \mathrm{ppb}$.

\subsection{1 $\mathrm{NO}_{2}$}

$\mathrm{NO}_{2}$ showed a clear diurnal variation (Fig. 2). Concentrations were highest in the early morning when vehicle traffic as well as oil well machinery emissions became coincident with a stable nocturnal boundary layer. Turbulent mixing in the afternoon diluted the concentration, giving a minimum at 16:00 local time (MST). The multi-day effect of high/low wind episodes on $\mathrm{NO}_{2}$ concentration is visible in Fig. 1, with high wind speed always corresponding to low $\mathrm{NO}_{2}$ levels.

\subsection{2 $\Sigma$ ANs}

The daily variation in $\Sigma$ ANs concentration is less pronounced than for $\mathrm{NO}_{2}$ but follows a similar multi-day trend 
Table 1. Median $\mathrm{OH}$ reactivity and associated formation rates at local noon.

\begin{tabular}{lccc}
\hline Compound class & OH reactivity $\left(\mathrm{s}^{-1}\right)$ & $p(\Sigma \mathrm{ANs})^{*}\left(\mathrm{ppth}^{-1}\right)$ & $p\left(\mathrm{O}_{3}\right)^{*}\left(\mathrm{ppth}^{-1}\right)$ \\
\hline Alkane $\mathrm{C}_{1}-\mathrm{C}_{11}$ & 5.02 & 172 & 1760 \\
Alkene $\mathrm{C}_{2}-\mathrm{C}_{3}$ & 0.15 & 0.71 & 44 \\
Alkyne $\mathrm{C}_{2}$ & 0.013 & 0 & 2.4 \\
Aromatic $\mathrm{C}_{6}-\mathrm{C}_{9}$ & 0.58 & 0.90 & 120 \\
Alcohol $\mathrm{C}_{1}-\mathrm{C}_{2}$ & 0.31 & 0 & 48 \\
Ketone $\mathrm{C}_{3}-\mathrm{C}_{4}$ & 0.0084 & $\sim 0$ & 0.37 \\
Aldehyde $\mathrm{C}_{1}-\mathrm{C}_{4}$ & 0.44 & 0 & 130 \\
$\mathrm{CO}$ & 0.95 & 0 & 150 \\
$\mathrm{NO}$ & 0.61 & 0 & 0 \\
$\mathrm{NO}_{2}$ & 0.82 & 0 & 0 \\
\hline Total & 8.90 & 174 & 2250 \\
\hline
\end{tabular}

* Median noon time $[\mathrm{OH}]=1 \times 10^{6}$ molecule $\mathrm{cm}^{-3}$.

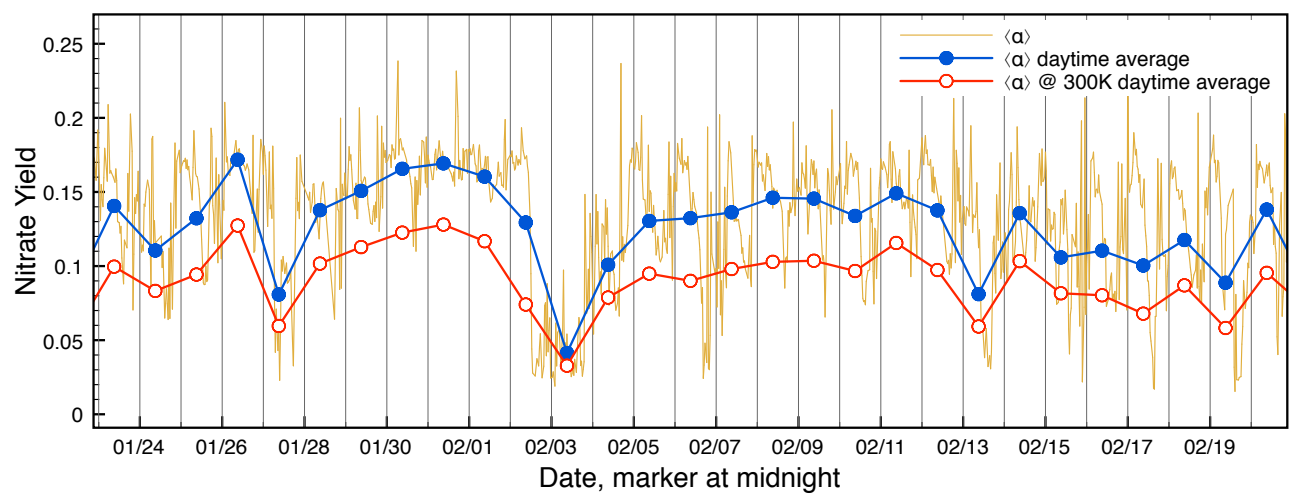

Figure 3. Ensemble-averaged nitrate formation yield $(\langle\alpha\rangle)$ calculated based on the method in Sect. 3.2.1. Blue symbols represent daytime average of the hourly $\langle\alpha\rangle$ (in orange) estimated at $273 \mathrm{~K}$, representative of the campaign period conditions. The red symbols are the daytime averaged $\langle\alpha\rangle$ estimated at $300 \mathrm{~K}$, routinely used in global models.

controlled by meteorology. As shown in Fig. 2, the total $\mathrm{RONO}_{2}$ concentration increases in the morning to a noontime peak of $1.5 \mathrm{ppb}$. The contributions from $\mathrm{C}_{1}-\mathrm{C}_{3}$ alkyl nitrates measured by gas chromatography-mass spectrometry (GC-MS) are small and nearly constant at $\sim 50 \mathrm{ppt}$ and did not contribute to the diurnal profile observed.

\subsection{3 $\mathrm{O}_{3}$}

The observed $\mathrm{O}_{3}$ concentration ranged from 4 to $50 \mathrm{ppb}$ and was negatively correlated with $\mathrm{NO}_{2}$. The diurnal profile has a maximum concentration in the late afternoon, corresponding to a delay of roughly $4 \mathrm{~h}$ from the peak of organic nitrates. The increase in $\mathrm{O}_{3}$ concentration is most rapid $\left(\sim 2.4 \mathrm{ppbh}^{-1}\right)$ at noon.

\subsubsection{VOCs}

The VOC composition is heavily influenced by the fossil fuel extraction operations. Alkane oxidation dominates the chemistry in the basin (Table 1), accounting for $67 \%$ of total mea- sured VOC reactivity $\left(7.5 \mathrm{~s}^{-1}\right)$ at noon. The diurnal profile of VOCs follows $\mathrm{NO}_{2}$, reaching a minimum in the late afternoon (see Fig. 3a in Edwards et al., 2013).

\subsection{The average branching ratio for nitrate formation}

The average noontime temperature during the UBWOS experiment was $0^{\circ} \mathrm{C}$. These cold temperatures provide a unique opportunity to examine the role of temperature in the formation of organic nitrates and the associated radical chain termination compared with other field campaigns taking place in summer.

Organic nitrate compounds are formed via $\mathrm{OH}$-initiated oxidation. For the specific mixture of VOCs observed, the dominant reaction starts with hydrogen abstraction from alkanes by $\mathrm{OH}$. The resulting alkyl radical rapidly reacts with $\mathrm{O}_{2}$ to give an alkyl peroxy radical $\mathrm{RO}_{2}$, which subsequently reacts with $\mathrm{NO}$ to form an energy-rich adduct of the structure ROONO* (Reaction R1). Under typical atmospheric conditions, a fraction (Reaction R2) of ROONO* is collisionally stabilized to form the nitrooxy group, $\mathrm{RONO}_{2}$, 
while the unstabilized portion (Reaction R3) dissociates to yield an alkoxy radical and $\mathrm{NO}_{2}$. The fate of the alkoxy radical varies depending on the carbon backbone but, in general, an $\mathrm{HO}_{2}$ radical is returned.

$$
\begin{array}{ll}
\mathrm{RO}_{2}+\mathrm{NO} \rightarrow \mathrm{ROONO}^{*} \\
\mathrm{ROONO}^{*}+M \rightarrow \mathrm{RONO}_{2}+M \\
(1-\alpha) & \mathrm{ROONO}^{*} \rightarrow \mathrm{RO}+\mathrm{NO}_{2}
\end{array}
$$

Given a rate of $\mathrm{VOC}$ reaction with $\mathrm{OH}$, the key factor regulating $\mathrm{RONO}_{2}$ production is the nitrate branching ratio, $\alpha$, defined as the overall fraction of the $\mathrm{RO}_{2}+\mathrm{NO}$ reaction that gives an organic nitrate product rather than an alkoxy radical and $\mathrm{NO}_{2}$ product. The association reaction to form $\mathrm{RONO}_{2}$ is compound-specific and temperature- and pressure-dependent (Atkinson et al., 1983). In the subsequent sections, we present two independent methods for estimating ensemble-averaged $\alpha$ values (or $\langle\alpha\rangle$ ) for the specific environment of the UBWOS campaign, and demonstrate their agreement to within the uncertainty of our observations. The first method (Sect. 3.2.1) is based on parameterizations derived from laboratory experiments and the observed VOC composition data, while the second method (Sect. 3.2.2) uses the observed $\Sigma$ ANs concentration, photolysis, and VOC reactivity.

\subsubsection{VOC-ensemble method}

The averaged $\alpha,\langle\alpha\rangle$, is defined in Eq. (1) as the summation of compound-specific $\alpha$ values weighted by their relative importance in atmospheric oxidation calculated as the product of $\mathrm{OH}$ reaction rate constant and compound concentration (namely, the $\mathrm{OH}$ reactivity).

$$
\langle\alpha\rangle=\frac{\sum_{i} k_{i}\left[x_{i}\right] \alpha_{i}}{\sum_{j} k_{j}\left[x_{j}\right]}
$$

Here $\alpha_{i}$ denotes the compound-specific nitrate branching ratio, $k_{i}\left(k_{j}\right)$ the $\mathrm{OH}$ reaction rate constant, and $\left[x_{i}\right]\left(\left[x_{j}\right]\right)$ the concentration of species $i(j)$. The VOC OH reactivity, $k_{i}\left[x_{i}\right]$ $\left(k_{j}\left[x_{j}\right]\right)$, in the Uintah basin was dominated by alkanes (see Table 1). We point out here that the net effect of temperature on the $\mathrm{OH}$ reaction rate constants was generally small, typically a $5 \%$ reduction in total $\mathrm{OH}$ reactivity compared with $298 \mathrm{~K}$ values (Atkinson, 1994), and the dominant temperature dependence of organic nitrate production is due to the nitrate branching ratio as detailed below.

For $\alpha_{i}$ values specific to alkanes, we use temperature- and pressure-dependent, compound-specific $\alpha_{i}$ values (Carter and Atkinson, 1989) and include contributions of secondary organic nitrate formation after alkoxy radical isomerization reactions, which can be increasingly important for alkanes larger than butane. This increases the individual organic nitrate yield by up to $30 \%$, generally in proportion to the size of the molecule. The compound-specific $\alpha$ values are summarized in Table 2 .

The $\alpha_{i}$ values for aldehydes were treated as having the same nitrate yield as the $\mathrm{RO}_{2}$ having one less carbon, since the major reaction with $\mathrm{OH}$ involves aldehydic hydrogen abstraction and decomposition following reaction with $\mathrm{NO}$ to give a $\mathrm{CO}_{2}$ molecule and a $\mathrm{C}_{n-1}$ alkyl radical. The $\alpha_{i}$ values for ketones were estimated using the same method as detailed for alkanes. Methanol and ethanol are presumed to have zero nitrate yield, since their reactions with $\mathrm{O}_{2}$ after hydrogen abstraction to form carbonyls and $\mathrm{HO}_{2}$ are dominant. Finally, the nitrate yields for aromatics were set to $1 \%$ in this analysis, following the yield of benzyl nitrate from toluene oxidation (Gery et al., 1985; Atkinson and Aschmann, 1989; Atkinson, 1994). It is noted that even by assuming an upperlimit nitrate yield of 0.35 , the contribution from aromatic compounds to alkyl nitrate production is minor $(14 \%)$ relative to the production from alkanes.

The average nitrate formation yield, $\langle\alpha\rangle$, as calculated above including all VOC and CO measurements throughout the campaign period, is plotted in Fig. 3 as instantaneous values (blue filled symbol) and as a daytime (08:00-18:00 MST) average (red filled symbol). The organic nitrate yield ranged from $3 \%$ to $15 \%$ with low values corresponding to periods of high winds (e.g., 3 February). Variation in VOC concentration and composition is the dominant factor controlling the day-to-day variation as well as the variation over each day. Daytime-averaged values of $\langle\alpha\rangle$ calculated at a temperature of $300 \mathrm{~K}$ are shown in red. Even at $300 \mathrm{~K}$ the $\langle\alpha\rangle$ is significant, often around $10 \%$.

\subsubsection{Oxidation-production method}

Our second approach to estimating $\alpha$ is based primarily on the $\Sigma$ ANs measurements. In this case, $\langle\alpha\rangle$ can be expressed as the ratio of the $\Sigma$ ANs production rate over the total VOC consumption rate (Eq. 2).

$$
\begin{aligned}
& \langle\alpha\rangle=\frac{p(\Sigma \mathrm{ANs})}{[\mathrm{OH}] \cdot \sum_{i} k_{i}\left[x_{i}\right]} \\
& p(\Sigma \mathrm{ANs})=\frac{d(\Sigma \mathrm{ANs})}{d t}+k_{\mathrm{mix}} \cdot \Sigma \mathrm{ANs} \\
& {[\mathrm{OH}]=f\left(\sum_{i} k_{i}\left[x_{i}\right], J,\left\langle\alpha^{\prime}\right\rangle\right)}
\end{aligned}
$$

The individual terms in Eq. 2 can be derived from observations, as shown in Eqs. (3) and (4). The total production rate of $\Sigma$ ANs $(p(\Sigma$ ANs $))$ is expressed, according to mass balance, as the sum of the rate of change of the observed $\Sigma \mathrm{AN}$ concentration and an overall loss term in Eq. (3). Chemical losses of $\Sigma$ ANs are found to be negligible compared with turbulent mixing out of the boundary layer. To estimate the effective loss rate constant $k_{\text {mix }}$, we employ a tracer method by solving Eq. (3) using $n$-propyl nitrate concentrations mea- 
Table 2. Summary of specific organic nitrate yield $(\alpha)$ and ozone yield $(\gamma)$ calculated at $0{ }^{\circ} \mathrm{C}$.

\begin{tabular}{llllll}
\hline Compound Class & $\alpha$ & $\gamma$ & Compound Class & $\alpha$ & $\gamma$ \\
\hline Alkane & $\mathbf{0 . 2 2}$ & $\mathbf{2 . 2 5}$ & Alkene & $\mathbf{0 . 0 3 1}$ & $\mathbf{1 . 9 4}$ \\
methane & $\sim 0$ & 2 & ethene & 0.025 & 1.95 \\
ethane & 0.019 & 1.96 & propene & 0.05 & 1.9 \\
propane & 0.045 & 1.92 & & & \\
iso-butane & 0.11 & 2.6 & Alkyne & $\mathbf{0}$ & $\mathbf{1 . 2}$ \\
n-butane & 0.114 & 2.17 & ethyne & $\sim 0$ & 1.2 \\
iso-pentane & 0.21 & 2.46 & & & \\
n-pentane & 0.2 & 2.19 & Aromatic & $\mathbf{0 . 0 1}$ & $\mathbf{1 . 3}$ \\
2,2-dimethylpropane & 0.25 & 3.1 & & & \\
n-hexane & 0.42 & 2.62 & Alcohol & $\mathbf{0}$ & $\mathbf{1}$ \\
2,2-dimethylbutane & 0.36 & 2.7 & methanol & $\sim 0$ & 1 \\
2-methylpentane & 0.29 & 2.2 & ethanol & $\sim 0$ & 1.05 \\
3-methylpentane & 0.33 & 2.34 & & & \\
methyl-cyclopentane & 0.29 & 2.9 & Ketone & $\mathbf{0 . 0 7 7}$ & $\mathbf{3 . 7 2}$ \\
Cyclohexane & 0.33 & 2 & acetone & 0.021 & 4 \\
methyl-cyclohexane & 0.58 & 2.4 & methylethylketone & 0.11 & 3.56 \\
ethyl-cyclohexane & 0.5 & 2.25 & & & \\
dimethyl-cyclohexane & 0.67 & 1.8 & Aldehyde & $\mathbf{0}$ & $\mathbf{1 . 9 6}$ \\
heptane & 0.6 & 2.2 & formaldehyde & 0 & 1 \\
octane & 0.6 & 1.86 & acetaldehyde & 0 & 3 \\
nonane & 0.62 & 1.52 & propanal & 0.019 & 3 \\
decane & 0.74 & 1.43 & butanal & 0.045 & 2.91 \\
undecane & 0.81 & 1.2 & methacrolein & 0.05 & 2.45 \\
\hline a Previously assumed value of 0.1 is due to contribution of nitrobenzene which we do not detect in 5 ANs \\
channel. & & & & & \\
b Assumption based on toluene data. & & & &
\end{tabular}

sured by GC-MS. We chose $n$-propyl nitrate because its expected loss is also dominated by mixing due to its long chemical lifetime, and its production rate can be calculated independently of measured VOC precursors. Note here that the $\mathrm{OH}$ concentration is needed to calculate the production rate of $n$-propyl nitrate, as well as the VOC consumption rate in the denominator of Eq. (2). The $\mathrm{OH}$ concentration is a function of VOC reactivity and photolysis rates ( $J$ values) as well as the $\alpha$ value for the radical recycling efficiency. Due to the dependence of the $\mathrm{OH}$ concentration on the nitrate yield, it is not possible to represent $\alpha$ in a closed functional form using all other variables. Therefore, the set of equations must be solved iteratively until a self-consistent $\alpha$ and $\mathrm{OH}$ concentration are obtained $\left(\langle\alpha\rangle=\left\langle\alpha^{\prime}\right\rangle\right.$, where $\langle\alpha\rangle$ is the implied value and $\left\langle\alpha^{\prime}\right\rangle$ is the initial guess).

The calculations proceed by calculating the following: (1) $\mathrm{OH}$ concentration and VOC consumption rate, (2) mixing rate estimates, (3) $\Sigma \mathrm{ANs}$ formation rate and $\langle\alpha\rangle$.

\section{OH concentration and VOC consumption rate}

We used photolysis rates of $\mathrm{O}_{3}, \mathrm{NO}_{2}, \mathrm{NO}_{3}, \mathrm{HONO}, \mathrm{ClNO}_{2}$, acetaldehyde, acetone, formaldehyde, and $\mathrm{HNO}_{3}$ to calculate $\mathrm{OH}$ and $\mathrm{HO}_{2}$ production rates. Photolysis rates for $\mathrm{O}_{3}, \mathrm{NO}_{2}$, and $\mathrm{NO}_{3}$ are measured directly with filter radiometers. For other species they are estimated using linear combination of photolysis rates of $\mathrm{O}_{3}$ and $\mathrm{NO}_{2}$. $\mathrm{OH}$ formation from alkene ozonolysis reactions was negligible. The median total radical production of $2.5{\mathrm{ppb} d a y^{-1}}^{-}$is similar to the value reported by Edwards et al. (2013). Data for $\mathrm{NO}, \mathrm{NO}_{2}$, and VOCs coupled with literature values of $\mathrm{OH}$ reaction rate constants corrected for campaign-measured temperature and pressure dependence (Atkinson et al., 2004, 2006) were then used for $\mathrm{OH}$ and $\mathrm{HO}_{2}$ calculations including radical recycling. The resulting VOC consumption rate is shown in Fig. 4. Note that the VOC consumption rate profile conforms more to the shape of the radical source strength $\left(\mathrm{OH}\right.$ and $\mathrm{HO}_{2}$ formation rate derived from photolysis, same shape as solar irradiation) than to the $\mathrm{OH}$ concentration, consistent with the notion that VOCs are the major reaction partner with $\mathrm{OH}$.

\section{Mixing-rate estimation}

We estimate the dilution loss $\left(k_{\mathrm{mix}}\right)$ for $\Sigma \mathrm{ANs}$ concentration by substituting $n$-propyl nitrate concentration for [ $\Sigma$ ANs] in Eq. (3). The time derivative of $n$-propyl nitrate concentration was calculated using a finite difference method, followed by application of a $2 \mathrm{~h}$ running mean to smooth hourly data. Kinetic studies dictate that $\sim 24 \%$ of the $\mathrm{OH}$ reaction with propane at $273 \mathrm{~K}$ yielded a primary alkyl radical (Droege and 


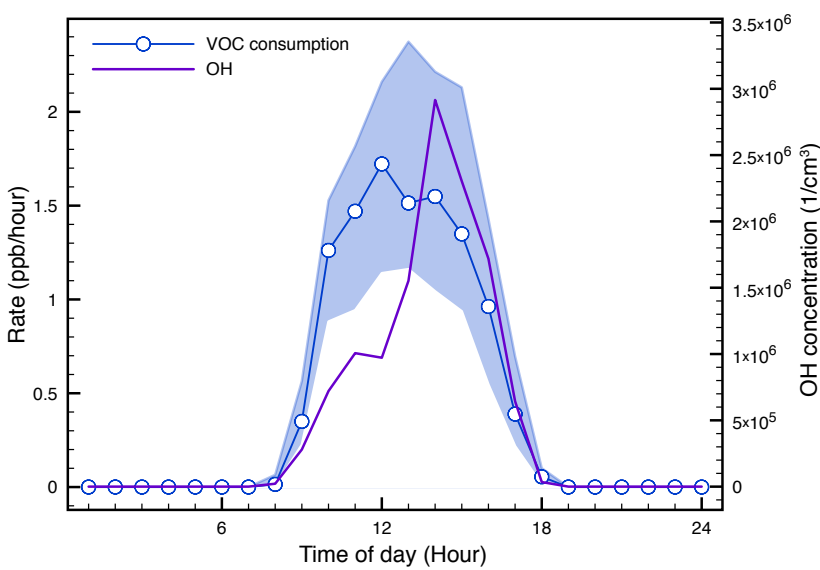

Figure 4. Calculated daytime median profiles of the VOC consumption rate and the $\mathrm{OH}$ concentration. The VOC consumption rate is controlled by the photolysis rate leading to $\mathrm{OH}$ and $\mathrm{HO}_{2}$ radical formation, while $\mathrm{OH}$ concentration is regulated by the $\mathrm{OH}$ reactivity dominated by the $\mathrm{NO}_{\mathrm{x}}$ and VOC concentrations.

Tully, 1986), which promptly reacted with $\mathrm{O}_{2}$ to form the corresponding peroxy radical. Larger alkane molecules can also yield $n$-propyl alkyl radical as a result of alkoxy radical decomposition from the appropriate structure, and we accounted for all such minor formation channels up to undecane to give a total additional contribution of $14 \%$ from sources other than propane. The total formation rate of $n$ propyl nitrate is presented in Fig. 5 as the red trace spanned by the 25th and 75th percentiles in the shaded area. Plotted in blue is the median value of the time derivative of $n$-propyl nitrate concentration, showing a diurnal pattern for which peak concentration was reached at noontime when the time derivative crosses the zero line. The initial concentration increase roughly coincides with the start of photochemical reaction, as is also marked by the onset of positive $n$-propyl nitrate formation rate. The negative portion of the blue trace in the afternoon then corresponds to faster dilution due both to turbulence and to the elevated concentration. These values are sufficient to solve for the time-varying dilution rate constant, $k_{\text {mix }}$, shown in Fig. 5 as green line with dashed traces bounding the interquartile range. Note the slight delay $(\sim 1 \mathrm{~h})$ in the daily maximum of the dilution rate constant when compared with the peak $n$-propyl nitrate formation rate. As vertical turbulence was promoted by surface heating, this delay is a reasonable consequence of the expected lag in the mixing rate. The median daily maximum mixing rate shows a time constant of $6 \mathrm{~h}$, much more rapid than other loss processes such as the $\mathrm{OH}$ oxidative lifetime of $n$-propyl nitrate of over $150 \mathrm{~h}$ under the $\mathrm{OH}$ concentration of $2 \times 10^{6} \mathrm{~cm}^{-3}$ (Fig. 4) and a photolysis lifetime of over $200 \mathrm{~h}$ (Luke et al., 1989), consistent with our initial assumption that chemical losses are small.

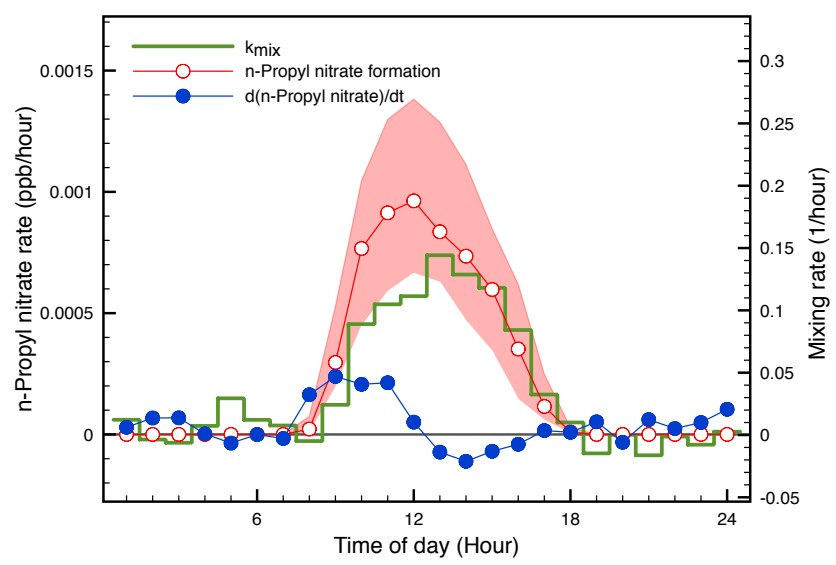

Figure 5. The production rate and concentration change of $n$-propyl nitrate calculated from field observations. The difference between the red and blue traces represents the mixing loss promoted by solar surface heating. The green trace is the calculated effective first-order mixing rate, $k_{\text {mix }}$. The red shaded area represents the interquartile (25-75\%) coverage for $n$-propyl nitrate formation.

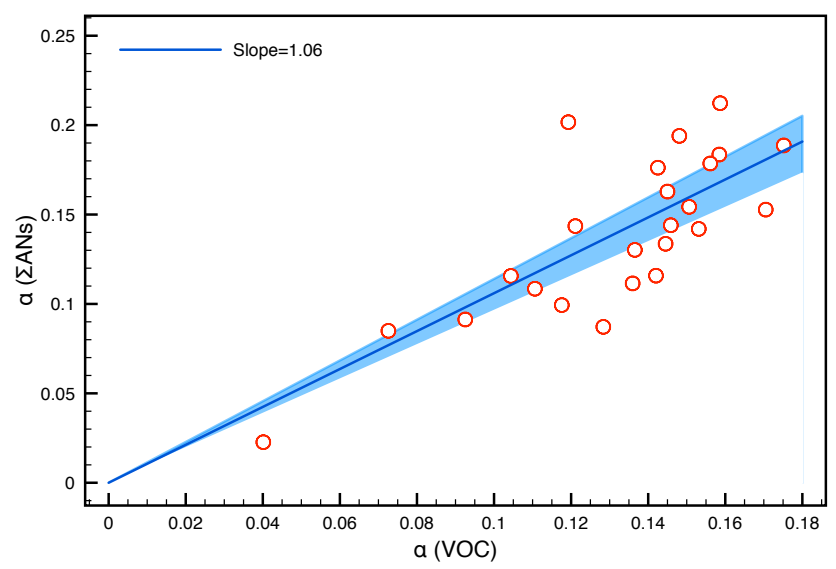

Figure 6. Correlation between daytime-averaged $\alpha$ estimated using the VOC-ensemble method (Sect. 3.2.1) and the oxidationproduction method (Sect. 3.2.2). The shaded area corresponds to the $95 \%$ confidence interval for the regression slope passing through the origin. The $1: 1$ line is within this interval.

\section{$\Sigma$ ANs formation rate and $\langle\alpha\rangle$}

Using the $k_{\text {mix }}$ value calculated above, the $\Sigma$ ANs formation rate was estimated using Eq. (3). We then inserted this $\Sigma$ AN formation rate and VOC consumption rate back into Eq. (2) to obtain the implied $\langle\alpha\rangle$ value based on the field observations and also on the initial guess of $\left\langle\alpha^{\prime}\right\rangle$. For time periods when $\langle\alpha\rangle$ mismatches $\left\langle\alpha^{\prime}\right\rangle,\left\langle\alpha^{\prime}\right\rangle$ is adjusted toward $\langle\alpha\rangle$ accordingly and the calculation repeated to achieve consistency. To reduce the number of points needed for calculation, we only estimated one self-consistent $\langle\alpha\rangle$ value for each day by averaging from 08:00 to 18:00 MST, the same as the averaging window used for our first method. 
Direct comparison of the estimate from Sect. 3.2.2 with the one derived from just the VOC composition (Sect. 3.2.1) is shown in Fig. 6. There were 27 days to compare and the two methods agree closely, yielding a slope of 1.06 and $R^{2}=0.61$. The similarity in results of the two methods lends support to the estimates of $\alpha$ and confirms the importance of a significant temperature dependence to the value of $\alpha$ affecting the UBWOS chemistry.

\section{Discussion}

The relatively high value observed for the average nitrate yield, $\langle\alpha\rangle$, of $\sim 15 \%$, is a direct consequence of low temperatures and the presence of heavy alkanes, a special condition created by natural gas and oil extraction operations in the basin. In the following sections, we discuss how this elevated nitrate yield affects the fate of $\mathrm{NO}_{\mathrm{x}}$ emitted into the basin and the rate of local $\mathrm{O}_{3}$ production.

\subsection{Fate of $\mathrm{NO}_{\mathrm{x}}$}

Organic nitrate formation was a significant chemical loss for $\mathrm{NO}_{\mathrm{x}}$ in the Uintah Basin. We calculated that alkyl nitrate formation is $50 \%$ faster than $\mathrm{HNO}_{3}$ formation during the low wind periods, $0.23 \mathrm{ppbh}^{-1}$ vs. $0.16 \mathrm{ppbh}^{-1}$ using the estimated noontime $\mathrm{OH}$ concentration. Together, this amounts to an $\mathrm{NO}_{\mathrm{x}}$ chemical lifetime of $17 \mathrm{~h}$, with relative branching of $59 \%$ to alkyl nitrate formation and $41 \%$ to $\mathrm{HNO}_{3}$ formation. Peroxyacetyl nitrate (PAN) and other peroxyacyl nitrate compounds were not observed to have high production rates, based on measured $\Sigma$ PNs and PAN concentration and direct calculation of their formation rate from VOC composition including aldehydes. We estimate a lower and upper limit in noontime median net production of 0.01 to $0.06 \mathrm{ppb} \mathrm{PAN} \mathrm{h}^{-1}$, using bottom-up (VOC speciation) and top-down (observed PAN concentration and dilution rate assuming zero background PAN concentration) methods, respectively. This corresponds to PAN representing a maximum of $\sim 18 \%$ of the $\mathrm{NO}_{\mathrm{x}}$ sink. Alkyl nitrate formation is therefore the single most important chemical loss pathway for $\mathrm{NO}_{\mathrm{x}}$ as well as the most important terminator for $\mathrm{OH}$ chain propagation. Note that, although $\Sigma \mathrm{AN}$ formation is the largest chemical sink, mixing out of the basin is the dominant overall loss for $\mathrm{NO}_{\mathrm{x}}$ emitted. We estimate $68 \%$ of $\mathrm{NO}_{\mathrm{x}}$ loss is to transport out of the basin.

\section{$4.2 \mathrm{O}_{3}$ formation}

$\mathrm{O}_{3}$ formation is closely related to the formation of organic nitrates, since the reaction channels lead from a branching point in a common pathway. Similar to our treatment of VOC-specific $\alpha$ values, we calculated, for each measured VOC molecule, the average number of $\mathrm{O}_{3}$ molecules generated in a single event of $\mathrm{OH}$-initiated oxidation, denoted as $\gamma$ in Table 2. Note that our definition and estimate for $\gamma$

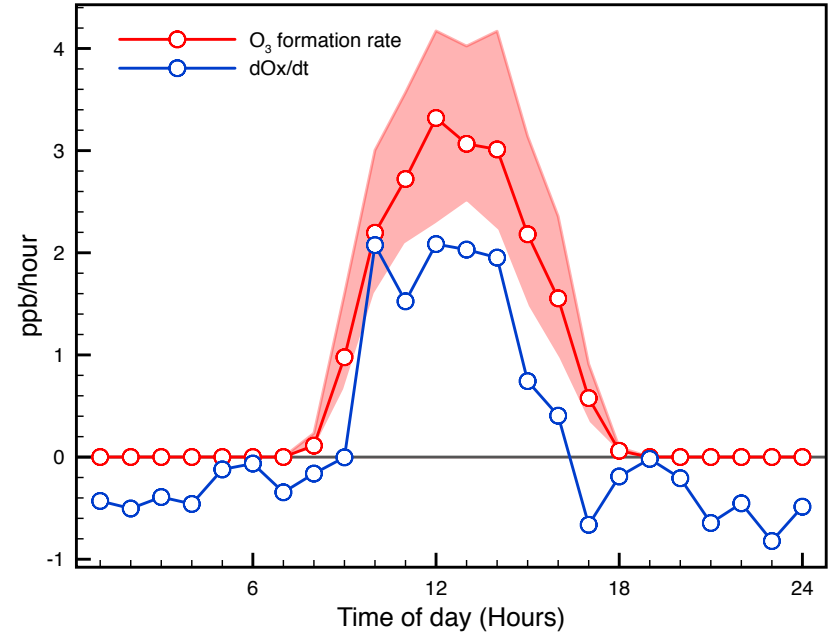

Figure 7. Calculated daytime $\mathrm{O}_{3}$ formation rate and the rate of change of $\mathrm{O}_{\mathrm{x}}\left(\mathrm{NO}_{2}+\mathrm{O}_{3}\right)$ observed. The difference between traces can be attributed to mixing using the same mixing rate estimated from $n$-propyl nitrate. The existence of non-negligible background $\mathrm{O}_{3}$ concentration ( $30 \mathrm{ppb}$ ) suppresses the net dilution.

includes the contribution from multi-generation alkyl nitrate formation, making it slightly different from previous calculations (Rosen et al., 2004; Perring et al., 2013; Farmer et al., 2011) (see Appendix $\mathrm{C}$ ). The $\mathrm{O}_{3}$ production rate is then a product of the ensemble-averaged $\gamma$ and the VOC consumption rate calculated above, as plotted in Fig. 7. The difference between the $\mathrm{O}_{3}$ production rate and the rate of change in $\mathrm{O}_{3}$ concentration signifies the contribution of mixing into the background air. When compared with the production characteristics of $n$-propyl nitrate in Fig. 4 , it is apparent that dilution loss is much more important for the case of $n$-propyl nitrate $\left(>80 \%\right.$ of the formation rate) than for $\mathrm{O}_{3}(\sim 30 \%$ of the formation rate). Using the $k_{\text {mix }}$ value derived from $n$-propyl nitrate formation, the local $\mathrm{O}_{3}$ budget of the whole campaign period can be closed with a background $\mathrm{O}_{3}$ concentration in the range of 20-35 ppb, consistent with observations during high wind periods. This also reinforces the notion that our estimate for turbulent mixing is representative. To reproduce the short-term variations in $\mathrm{O}_{3}$ production over a $72 \mathrm{~h}$ period with a fixed background $\mathrm{O}_{3}$ level of $30 \mathrm{ppb}$, we estimate the expected change in $\mathrm{O}_{\mathrm{x}}\left(\mathrm{O}_{3}+\mathrm{NO}_{2}\right)$ concentration using the mass balance equation (Eq. 3) to find reasonable agreement with the observations (Fig. 8).

Regarding the relative production of $\mathrm{O}_{3}$ to $\Sigma$ ANs, the average $p\left(\mathrm{O}_{3}\right) / p(\Sigma$ ANs $)$ calculated as $\gamma / \alpha$ for UBWOS is 15. For comparison, a value of 6.2-7.5 was reported for the Deep Water Horizon (DWH) plume study (Neuman et al., 2012). While both plumes were dominated by alkanes, the VOC suite for the DWH study was further enriched in heavier organics. This is consistent with the understanding that alkyl nitrate yield increases with the carbon number of the precursor alkane. By comparison, a typical industrial city plume 
Table 3. Expected maximum $\mathrm{O}_{\mathrm{x}}\left(\mathrm{NO}_{2}+\mathrm{O}_{3}\right)$ concentration under UBWOS conditions.

\begin{tabular}{lll}
\hline Condition $^{\mathrm{a}}$ & $\begin{array}{c}\text { UBWOS 2012 } \\
\text { base condition }\end{array}$ & $\begin{array}{l}\text { photolysis } \times 2 \\
\text { and mixing /2 }\end{array}$ \\
\hline$\alpha$ calculated at $273 \mathrm{~K}^{\mathrm{b}}$ & $57 \mathrm{ppb}$ & $140 \mathrm{ppb}$ \\
$\alpha$ calculated at $300 \mathrm{~K}^{\mathrm{b}}$ & $64 \mathrm{ppb}$ & $165 \mathrm{ppb}$ \\
difference & $7 \pm 4 \mathrm{ppb}^{\mathrm{c}}$ & $25 \pm 15 \mathrm{ppb}^{\mathrm{c}}$ \\
\hline a Assuming background $\mathrm{O}_{3}$ concentration of 30 ppb. \\
b Carter and Atkinson $(1989)$. \\
c Uncertainty due to temperature-dependence parameterization of alkyl nitrate \\
yield.
\end{tabular}

(Rosen et al., 2004) measured around Houston during Texas Air Quality Study 2000 has a value of $29-41$, a direct result of low $\alpha$ value (6.5-4.7\%) caused by high temperature $\left(\sim 40^{\circ} \mathrm{C}\right)$ and a relatively low contribution from large alkanes.

\subsection{Temperature}

Currently, none of the chemical mechanisms commonly employed in the chemical transport models for regional $\mathrm{O}_{3}$ predictions have incorporated the temperature dependence of alkyl nitrate yields. Since alkyl nitrate formation is a radical termination reaction, reduction in temperature decreases the $\mathrm{OH}$ recycling probability and shortens the $\mathrm{OH}$ radical chain length. For the 2012 UBWOS campaign the effect is to reduce the radical propagation chain length from a noontime median of $3.2(300 \mathrm{~K})$ to $2.6(273 \mathrm{~K})$. Since the chain length is directly proportional to the $\mathrm{O}_{3}$ production rate, this corresponds to a $20 \%$ decrease in the $\mathrm{O}_{3}$ formation rate. Table 3 shows the estimated maximum $\mathrm{O}_{\mathrm{x}}$ concentration in a multiday low wind accumulation event in the Uintah Basin based on the observed alkyl nitrate yield. We compare a calculation at $300 \mathrm{~K}$ to one at $273 \mathrm{~K}$. Note that for a snowless winter condition, such as encountered in UBWOS 2012, the prediction matches well with the observed maximum hourly $\mathrm{O}_{\mathrm{x}}$ concentration of $51 \mathrm{ppb}$ in the afternoon of 18 February 2012. While estimating the $\alpha$ value at $300 \mathrm{~K}$ always yields a higher predicted $\mathrm{O}_{3}$ concentration, the over prediction is greatest for the simulated snow condition (right most column) when persistent snow cover increases the photolysis rate and stabilizes the boundary layer impeding mixing.

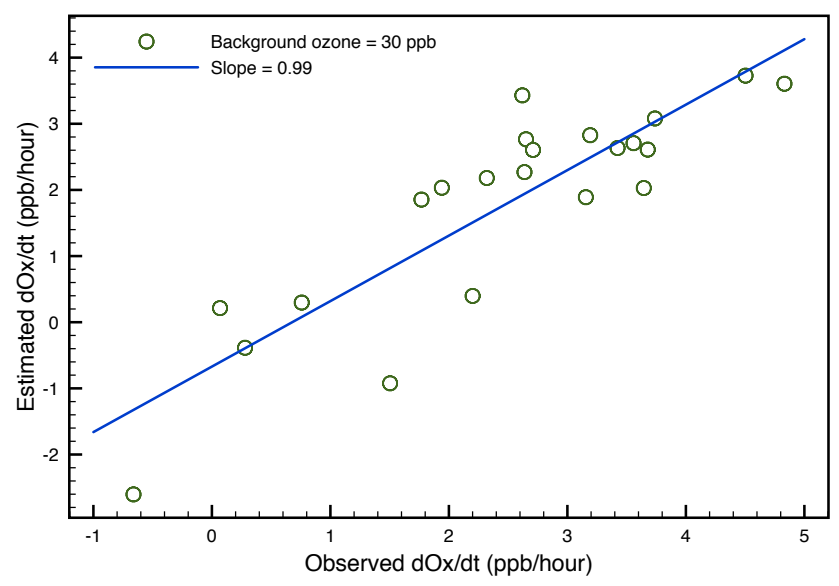

Figure 8. Correlation of the estimated daytime hourly $\mathrm{O}_{3}$ production rate corrected for dilution loss to what was observed from $\mathrm{O}_{3}$ and $\mathrm{NO}_{2}$ data. A background $\mathrm{O}_{3}$ concentration of $30 \mathrm{ppb}$ was assumed.

\section{Conclusion}

We have presented an analysis of field observations obtained in the Uintah Basin during winter 2012 in Utah, USA. We find that the field data can be used to derive the temperature dependence of the ensemble-averaged nitrate yield, $\langle\alpha\rangle$, and that this value is consistent with a parameterization derived from laboratory experiments. Including the proper temperature dependence based on the dominating VOC species should be considered for models aimed at estimating local $\mathrm{O}_{3}$ concentrations in order to avoid substantial errors $(+15 \%$ at $0{ }^{\circ} \mathrm{C}$ from $27^{\circ} \mathrm{C}$ values). 


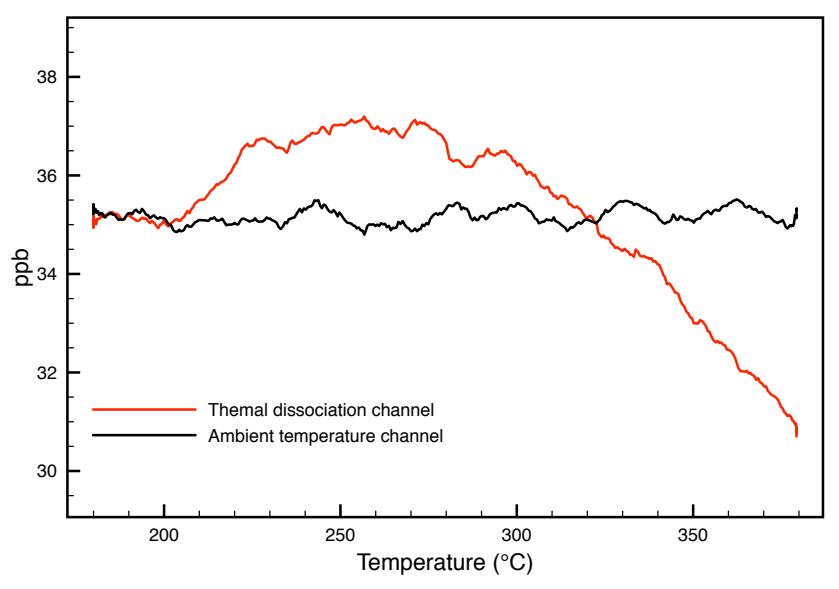

Figure A1. Laser-induced fluorescence signal from samples containing $\sim 35 \mathrm{ppb} \mathrm{NO}_{2}$ and $2 \mathrm{ppb}$ 2-ethylhexyl nitrate passing through the unheated channel (ambient temperature, black trace) and thermal dissociation channel (red trace) in the presence of $\mathrm{O}_{3}$.

\section{Appendix A: $\mathrm{O}_{3}$ pyrolysis correction for $\Sigma \mathrm{ANs}$ $\left(380^{\circ} \mathrm{C}\right)$ channel}

The cause of $\left(380^{\circ} \mathrm{C}\right)$ channel interference was $\mathrm{O}_{3}$ pyrolysis to yield an $\mathrm{O}$ atom at this elevated temperature in the TD oven. In the absence of organic molecules, the $\mathrm{O}$ atom can serve as a promoter for $\mathrm{NO}$ and $\mathrm{NO}_{2}$ interconversion reactions, as illustrated in Reactions R4-R7.

$$
\begin{aligned}
& \mathrm{O}_{3}+M \rightarrow \mathrm{O}_{2}+\mathrm{O}+M \\
& \mathrm{O}_{2}+\mathrm{O}+M \rightarrow \mathrm{O}_{3}+M \\
& \mathrm{NO}_{2}+\mathrm{O} \rightarrow \mathrm{NO}+\mathrm{O}_{2} \\
& \mathrm{NO}+\mathrm{O}+M \rightarrow \mathrm{NO}_{2}+M
\end{aligned}
$$

$\mathrm{NO}$ and $\mathrm{NO}_{2}$ are interconverted at a cost of one $\mathrm{O}$ atom whose steady-state concentration is generally controlled by the forward and reverse Reactions (R4) and (R5). If sufficient time is allowed, $\mathrm{NO}$ and $\mathrm{NO}_{2}$ will ultimately reach an equilibrium ratio which can be calculated from the reaction rates $k_{\mathrm{R} 5}$ and $k_{\mathrm{R} 6}$ (of Reactions $\mathrm{R} 5$ and $\mathrm{R} 6$, respectively) with pressure dependence. From the $\mathrm{O}_{3}$ pyrolysis rate and the gas residence time of $0.17 \mathrm{~s}$ in our TD oven region, only the $\Sigma$ ANs channel at $380{ }^{\circ} \mathrm{C}$ should generate sufficient $\mathrm{O}$ atom to alter the $\mathrm{NO}_{2}$ concentration significantly. To confirm this effect, we performed a series of lab experiments under $\mathrm{NO}_{\mathrm{x}}$ and $\mathrm{O}_{3}$ concentrations covering the range observed during the UBWOS campaign in the presence of $\sim 2 \mathrm{ppb}$ of 2-ethylhexyl nitrate, a simple alkyl nitrate standard available from Sigma-Aldrich as a surrogate for the collection of $\Sigma$ ANs in Utah. Figure A1 demonstrates the results of a temperature scan experiment when the inlet oven temperature of cell 1 was scanned upward from 180 to $380^{\circ} \mathrm{C}$, the operating temperature of the $\Sigma$ ANs channel in the field. The red trace represents the $\mathrm{NO}_{2}$ signal from cell 1 , while the black trace is the $\mathrm{NO}_{2}$ signal from cell 3 whose inlet was unheated. Since there was no peroxy nitrate in the system, at $180^{\circ} \mathrm{C}$ cell 3 only detects the same amount of $\mathrm{NO}_{2}$ as the ambient temperature cell 1 . However, starting from $\sim 200^{\circ} \mathrm{C}$ alkyl nitrate started to dissociate thermally, giving extra $\mathrm{NO}_{2}$ signal as the red trace increased relative to the black trace. The proper setting for $\Sigma$ ANs observations would be in the 250 to $280^{\circ} \mathrm{C}$ range in this instance. At temperatures beyond $280^{\circ} \mathrm{C}$ effects due to $\mathrm{O}_{3}$ pyrolysis started to reduce the excess $\mathrm{NO}_{2}$ signal, presumably by the interconversion reaction mentioned above, and we see the red trace eventually dropping below the black trace at around $320^{\circ} \mathrm{C}$. This interference thus generated substantial negative $\Sigma$ ANs signal when the $180^{\circ} \mathrm{C}$ channel is subtracted from the $380^{\circ} \mathrm{C}$ channel. Indeed, significant portions of uncorrected nighttime $\Sigma$ ANs signal throughout the campaign yielded negative values including negative spikes correlated with positive $\mathrm{NO}_{2}$ spikes from nearby road traffic emissions. This effect was most prominent when a high $\mathrm{NO}_{2}$ concentration existed, so that the excess $\Sigma$ ANs signal was relatively small on the $380^{\circ} \mathrm{C}$ channel. Considering that under the same $\mathrm{O}_{3}$ concentration the fraction of $\mathrm{NO}_{2}$ converted due to O-atom chemistry was a constant, larger overall $\mathrm{NO}_{2}$ concentration corresponded to a larger overall $\mathrm{NO}_{2}$ reduction, which could easily overwhelm the original $\Sigma$ ANs signal to introduce negative values when the high-temperature channel was subtracted from lower-temperature ones. For example, we have performed high-temperature box-model simulations on $\mathrm{O}_{3}$ pyrolysis reactions inside the TD oven with a residence time of $0.17 \mathrm{~s}$. At an $\mathrm{O}_{3}$ concentration of $30 \mathrm{ppb}$ the amount of $\mathrm{NO}_{2}$ loss through the $380^{\circ} \mathrm{C}$ channel was around $6 \%$. This indicates that if the $\Sigma$ ANs fraction within a sample is less than $6 \%$ of the total concentration from $\mathrm{NO}_{2}, \Sigma \mathrm{PNs}$, and $\Sigma$ ANs combined, a negative value will result. The O-atom chemistry outlined in Reactions (R4)-(R7) was further complicated by the presence of organics, especially when initial $\mathrm{NO}_{2}$ concentration was small, since signal loss in lab experiments was always more than can be explained in the absence of organics. Since we were uncertain of the effect of possible chain reactions involving organic radicals initiated by $\mathrm{O}$ atom, an empirical equation derived directly from inlab observations under $\mathrm{NO}_{\mathrm{x}}$ and $\mathrm{O}_{3}$ concentrations relevant to UBWOS condition was used for such corrections. Equation (A1) shows the relation of fractional signal lost, $r$, as a function of the observed total signal $S_{380}$ of the $380^{\circ} \mathrm{C}$ channel $\left(\mathrm{NO}_{2}+\Sigma \mathrm{PNs}+\Sigma \mathrm{ANs}\right)$ and $\mathrm{O}_{3}$ concentration, with all parameters obtained through fitting of experimental data. The corrected signal $\left(S_{380}^{\prime}\right)$ was thus obtained with Eq. (A2).

$$
\begin{aligned}
& r=\left(0.0694 \times \ln \left(S_{380}\right)-0.308\right) \times\left(0.0115 \times\left[\mathrm{O}_{3}\right]+0.557\right) \\
& S_{380}^{\prime}=\frac{S_{380}}{1+r}
\end{aligned}
$$




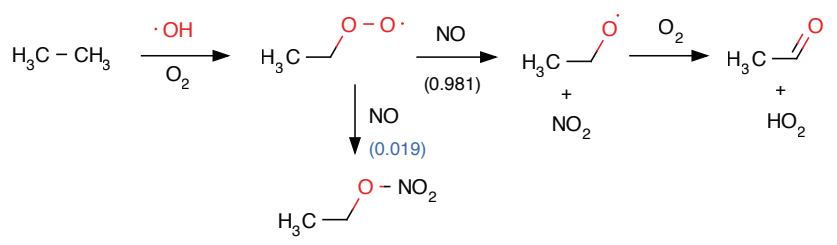

Figure B1. Ethane oxidation by $\mathrm{OH}$ radical in the presence of NO.

\section{Appendix B: VOC $\alpha$ calculation considering multiple generation $\mathrm{RO}_{2}$ formation}

Explicit examples for calculating $\alpha$ are given in the following sections for $\mathrm{OH}$-initiated oxidation of ethane and propane in the presence of NO. Further generalizations to other organics are also described.

\section{B1 $\alpha$ for ethane}

Estimating $\alpha$ for ethane is relatively straightforward. Daytime oxidation of ethane starts with an initial hydrogen abstraction by $\mathrm{OH}$ radical followed by $\mathrm{O}_{2}$ addition to the alkyl radical formed. Only a single isomer of alkyl peroxy radical is involved and no significant decomposition channel exists for the ethyl alkoxy radical formed from NO reaction that does not yield organic nitrate, as shown in Fig. B1. The numbers in parentheses are specific branching ratio of the processes represented. Branching ratios yielding organic nitrates are colored in blue. The overall nitrate branching ratio in this simple case is the same as the specific branching ratio of the ethylperoxy radical at 0.019 .

\section{B2 $\alpha$ for propane}

To calculate the overall nitrate yield for propane, the dominant product channels should be traced, as illustrated in Fig. B2. Two isomers are formed through hydrogen abstraction on either the primary or secondary carbon, giving $n$-propylperoxy and iso-propylperoxy radicals in a relative yield of 24 and $76 \%$, respectively. The overall nitrate branching ratio can then be calculated if the specific $\alpha$ for each peroxy isomer is known. Starting from $n$-propylperoxy radical, the direct reaction with NO gives $n$-propyl nitrate with a relative yield of $2.1 \%$ calculated according to the Carter-Atkinson method (1989) at $273 \mathrm{~K}$ and $842 \mathrm{mBar}$, representative of campaign conditions. The remaining portion of the channel proceeding through alkoxy radical reactions has a further branching of decomposition reaction (rather than reacting with $\mathrm{O}_{2}$ ) to form a formaldehyde and an ethyl radical which promptly reacts with $\mathrm{O}_{2}$ to give an ethylperoxy radical. The relative yield of decomposition versus $\mathrm{O}_{2}$ reaction can be calculated from the respective reaction rates reported in the literature. We used a decomposition rate of $846 \mathrm{~s}^{-1}$ (Curran, 2006) and the product of $\mathrm{O}_{2}$ reaction rate with $\mathrm{O}_{2}$ concentration, giving a first-order rate con- stant of $4 \times 10^{4} \mathrm{~s}^{-1}$ for the $\mathrm{O}_{2}$ channel. Branching ratios are hence $2 \%$ and $98 \%$ for decomposition and $\mathrm{O}_{2}$ reaction. The ethylperoxy radical from the decomposition channel can then react further with NO to give organic nitrates with a yield of 0.019, calculated in the previous section. Summing up both yields scaled by the individual channel strength, we have the specific nitrate yield of $n$-propylperoxy radical as $(0.019 \times 0.02 \times 0.979+0.021)=0.021$. Note that the correction from the additional ethylperoxy radical nitrate yield is almost negligible, due to the decomposition channel strength of only $2 \%$. However, for larger molecules, typically starting from $n$-butane, isomerization reactions can contribute substantially and higher-generation nitrate yield corrections are generally non-negligible. For iso-propylperoxy radical the specific nitrate yield was calculated using the same principle, only that after decomposition reaction a methylperoxy radical is formed. Since methylperoxy radical has little yield for methylnitrate formation, the total specific nitrate yield for iso-propylperoxy radical is just the direct yield of $5.2 \%$. The overall $\alpha$ for the propane-OH reaction is hence the ensemble average of the specific nitrate yield of all peroxy isomers, namely $(0.24 \times 0.021+0.76 \times 0.052)=0.045$.

\section{B3 $\alpha$ for higher alkanes and other organics}

Using the method detailed above for propane, we carried out an extended estimation for alkanes up to undecane, the largest alkane reported from GC-MS data. The results are summarized in Table 2. It is noted here that simplifications were necessary for these calculations. For example, in estimating $\alpha$ for more complex $\mathrm{RO}_{2}$ radicals from highergeneration oxidation products we ignored the possible contribution of other oxygen-containing functional groups to the estimated yield given by the Carter-Atkinson parameterization, so that only carbon number was considered. Further, rate constants used to estimate the relative branching ratios of alkoxy radical reactions were limited to available literature values, generally around $298 \mathrm{~K}$. As carbon chain length becomes longer, experimental data regarding $\mathrm{O}_{2}$ reaction, isomerization, and decomposition rates become scarce and the data available for the most similar structures are used.

\section{Appendix C: Differences in definition of $\gamma$ used in this paper}

The $\gamma$ value, used in this paper to denote the amount of $\mathrm{O}_{3}$ molecule generated from $\mathrm{OH}$-initiated oxidation of an organic molecule, is different from the definition in previous literature that focuses solely on single-generation $\mathrm{RO}_{2}$ chemistry in two aspects, as follows. First, $\gamma$ has commonly been given a value of 2 for two $\mathrm{O}_{3}$ molecules being generated per $\mathrm{OH}$-initiated oxidation of VOCs, one each from the formation of $\mathrm{HO}_{2}$ and $\mathrm{NO}_{2}$. This is a good approximation for small alkanes, for which isomerization is not important, but can be 


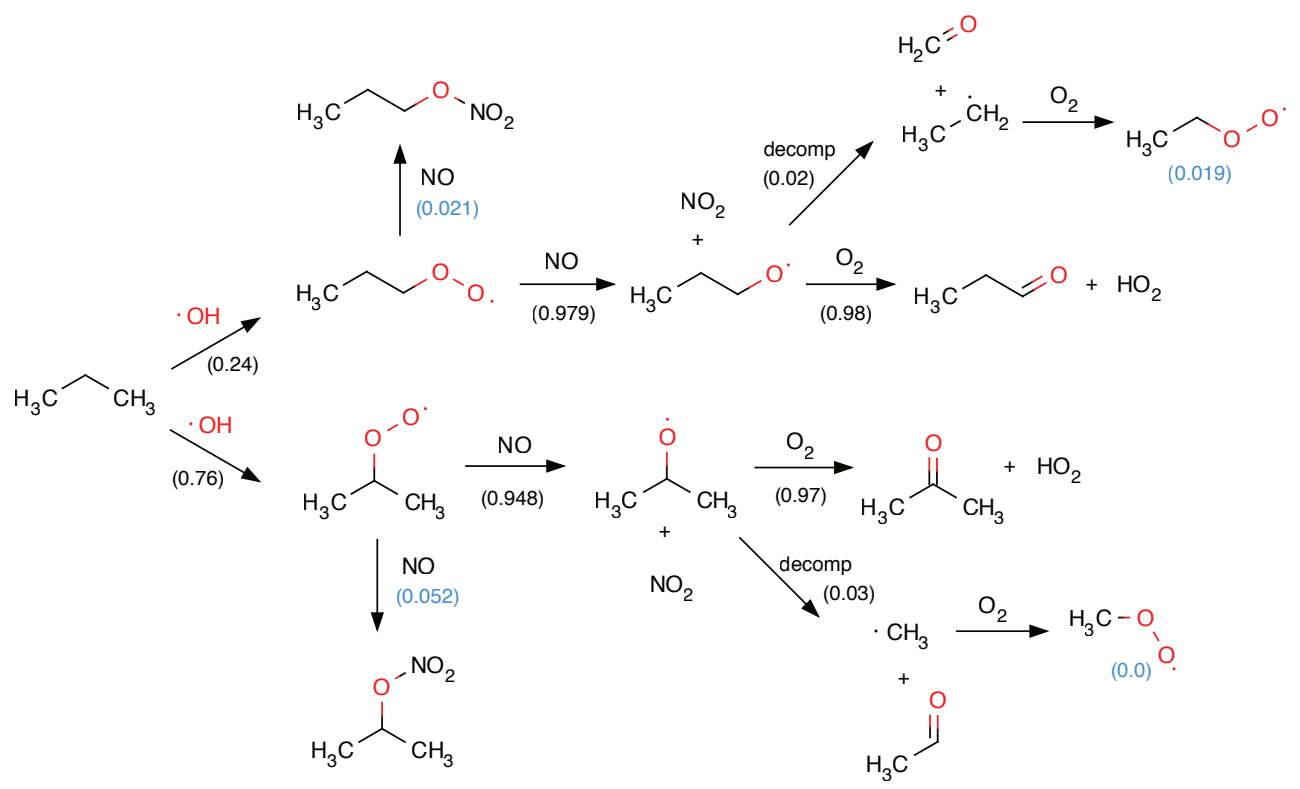

Figure B2. Propane oxidation by $\mathrm{OH}$ radical in the presence of $\mathrm{NO}$.

erroneous otherwise. For example, in the absence of the organic nitrate formation channel, we estimate $\gamma$ for $n$-hexane to be 3.2 due to the efficient isomerization reaction of hydrogen abstraction by the 2-alkoxy or 3-alkoxy radical produced, generating a new alkyl radical and an alcohol group. The presence of large alkanes, up to undecane, necessitates a more careful treatment. Second, $\gamma$ has been used to calculate the ratio of $\mathrm{O}_{3}$ production rate over $\Sigma$ ANs production rate, formulated as $\gamma(1-\alpha) / \alpha$. The factor $(1-\alpha)$ in the numerator implies that $\gamma$ was estimated under the assumption of zero nitrate formation. The factor $(1-\alpha)$ therefore accounted for the fraction of reaction that actually proceeded to form $\mathrm{O}_{3}$. This is only exact if $\mathrm{VOC}+\mathrm{OH}$ reaction only forms a single generation of $\mathrm{RO}_{2}$ molecule, once again a valid assumption for small VOC only. For larger alkanes there exists a non-negligible fraction of higher-generation $\mathrm{RO}_{2}$ reactions from isomerization reactions, and we must account for the effective numbers of $\mathrm{NO}_{2}$ and $\mathrm{HO}_{2}$ formed in a cumulative manner over extended generations. This means $\gamma$ and $\alpha$ are related according to the structure of the molecule under consideration. Our $\gamma$ values listed in Table 2 are then the better average number out of $\mathrm{O}_{3}$ generated per $\mathrm{OH}$-initiated oxidation with alkyl nitrate formation considered, or in the same spirit, the $\gamma(1-\alpha)$ value considered over multi-generation reactions. In Table 2, we observe an increasing trend of $\gamma$ going from methane to around hexane, since larger alkanes are more susceptible to isomerization and further radical reactions, converting more $\mathrm{NO}$ to $\mathrm{NO}_{2}$. This trend does not continue, however, with further increase of alkane size because of the competing effect of increasing organic nitrate yield, which eventually reduces the amount of alkoxy radical formed. 
Acknowledgements. The authors acknowledge the NOAA office of global programs: NA13OAR4310067 and NSF AGS-1120076 for their support of this research. The authors also acknowledge Jim Roberts for his hospitality and support in PAN, $\mathrm{HONO}$, and $\mathrm{ClNO}_{2}$ data, and Brian Lerner for VOC data.

Edited by: P. B. Shepson

\section{References}

Atkinson, R. and Aschmann, S. M.: Rate constants for the gasphase reactions of the $\mathrm{OH}$ radical with a series of aromatichydrocarbons at $296+/-2 \mathrm{~K}$, Int. J. Chem. Kinet., 21, 355-365, doi:10.1002/kin.550210506, 1989.

Atkinson, R.: Gas-Phase Tropospheric Chemistry of OrganicCompounds, J. Phys. Chem. Ref. Data, ISBN:156396340X, 1994.

Atkinson, R., Carter, W. P. L., and Winer, A. M.: Effects of temperature and pressure on alkyl nitrate yields in the $\mathrm{NO}_{\mathrm{x}}$ photooxidations of normal-pentane and normal-heptane, J. Phys. Chem., 87, 2012-2018, doi:10.1021/j100234a034, 1983.

Atkinson, R., Baulch, D. L., Cox, R. A., Crowley, J. N., Hampson, R. F., Hynes, R. G., Jenkin, M. E., Rossi, M. J., and Troe, J.: Evaluated kinetic and photochemical data for atmospheric chemistry: Volume $\mathrm{I}$ - gas phase reactions of $\mathrm{O}_{\mathrm{x}}, \mathrm{HO}_{\mathrm{x}}, \mathrm{NO}_{\mathrm{x}}$ and $\mathrm{SO}_{\mathrm{x}}$ species, Atmos. Chem. Phys., 4, 1461-1738, doi:10.5194/acp-41461-2004, 2004.

Atkinson, R., Baulch, D. L., Cox, R. A., Crowley, J. N., Hampson, R. F., Hynes, R. G., Jenkin, M. E., Rossi, M. J., Troe, J., and IUPAC Subcommittee: Evaluated kinetic and photochemical data for atmospheric chemistry: Volume II - gas phase reactions of organic species, Atmos. Chem. Phys., 6, 3625-4055, doi:10.5194/acp-6-3625-2006, 2006.

Carter, W. P. L. and Atkinson, R.: Alkyl Nitrate Formation From the Atmospheric Photooxidation of Alkanes - a Revised Estimation Method, J. Atmos. Chem., 8, 165-173, doi:10.1007/bf00053721, 1989.

Curran, H. J.: Rate constant estimation for C-1 to C-4 alkyl and alkoxyl radical decomposition, Int. J. Chem. Kinet., 38, 250-275, doi:10.1002/kin.20153, 2006.

Day, D. A., Wooldridge, P. J., Dillon, M. B., Thornton, J. A., and Cohen, R. C.: A thermal dissociation laser-induced fluorescence instrument for in situ detection of $\mathrm{NO}_{2}$, peroxy nitrates, alkyl nitrates, and $\mathrm{HNO}_{3}$, J. Geophys. Res.-Atmos., 107, ACH 4-1-ACH 4-14, doi:10.1029/2001jd000779, 2002.

Droege, A. T. and Tully, F. P.: Hydrogen-atom abstraction from alkanes by $\mathrm{OH}-3$. Propane, J. Phys. Chem., 90, 1949-1954, doi:10.1021/j100400a042, 1986.

Edwards, P. M., Young, C. J., Aikin, K., deGouw, J., Dube, W. P., Geiger, F., Gilman, J., Helmig, D., Holloway, J. S., Kercher, J., Lerner, B., Martin, R., McLaren, R., Parrish, D. D., Peischl, J., Roberts, J. M., Ryerson, T. B., Thornton, J., Warneke, C., Williams, E. J., and Brown, S. S.: Ozone photochemistry in an oil and natural gas extraction region during winter: simulations of a snow-free season in the Uintah Basin, Utah, Atmos. Chem. Phys., 13, 8955-8971, doi:10.5194/acp-13-8955-2013, 2013.

Farmer, D. K., Perring, A. E., Wooldridge, P. J., Blake, D. R., Baker, A., Meinardi, S., Huey, L. G., Tanner, D., Vargas, O., and Co- hen, R. C.: Impact of organic nitrates on urban ozone production, Atmos. Chem. Phys., 11, 4085-4094, doi:10.5194/acp-11-40852011, 2011.

Gery, M. W., Fox, D. L., Jeffries, H. E., Stockburger, L., and Weathers, W. S.: A continuous stirred tank reactor investigation of the gas-phase reaction of hydroxyl radicals and toluene, Int. J. Chem. Kinet., 17, 931-955, doi:10.1002/kin.550170903, 1985.

Goldan, P. D., Kuster, W. C., Williams, E., Murphy, P. C., Fehsenfeld, F. C., and Meagher, J.: Nonmethane hydrocarbon and oxy hydrocarbon measurements during the 2002 New England Air Quality Study, J. Geophys. Res.-Atmos., 109, D21309, doi:10.1029/2003jd004455, 2004.

Grund, C. J., Banta, R. M., George, J. L., Howell, J. N., Post, M. J., Richter, R. A., and Weickmann, A. M.: Highresolution Doppler lidar for boundary layer and cloud research, J. Atmos. Ocean. Tech., 18, 376-393, doi:10.1175/15200426(2001)018<0376:hrdlfb>2.0.CO;2, 2001.

Kliner, D. A. V., Daube, B. C., Burley, J. D., and Wofsy, S. C.: Laboratory investigation of the catalytic reduction technique for measurement of atmospheric NOy, J. Geophys. Res.-Atmos., 102, 10759-10776, doi:10.1029/96jd03816, 1997.

Luke, W. T., Dickerson, R. R., and Nunnermacker, L. J.: Direct measurements of the photolysis rate coefficients and Henry law constants of several alkyl nitrates, J. Geophys. Res.-Atmos., 94, 14905-14921, doi:10.1029/JD094iD12p14905, 1989.

Neuman, J. A., Aikin, K. C., Atlas, E. L., Blake, D. R., Holloway, J. S., Meinardi, S., Nowak, J. B., Parrish, D. D., Peischl, J., Perring, A. E., Pollack, I. B., Roberts, J. M., Ryerson, T. B., and Trainer, M.: Ozone and alkyl nitrate formation from the Deepwater Horizon oil spill atmospheric emissions, J. Geophys. Res.-Atmos., 117, D09305, doi:10.1029/2011jd017150, 2012.

Perring, A. E., Bertram, T. H., Wooldridge, P. J., Fried, A., Heikes, B. G., Dibb, J., Crounse, J. D., Wennberg, P. O., Blake, N. J., Blake, D. R., Brune, W. H., Singh, H. B., and Cohen, R. C.: Airborne observations of total $\mathrm{RONO}_{2}$ : new constraints on the yield and lifetime of isoprene nitrates, Atmos. Chem. Phys., 9, 1451-1463, doi:10.5194/acp-9-1451-2009, 2009.

Perring, A. E., Bertram, T. H., Farmer, D. K., Wooldridge, P. J., Dibb, J., Blake, N. J., Blake, D. R., Singh, H. B., Fuelberg, H., Diskin, G., Sachse, G., and Cohen, R. C.: The production and persistence of $\Sigma \mathrm{RONO}_{2}$ in the Mexico City plume, Atmos. Chem. Phys., 10, 7215-7229, doi:10.5194/acp-10-72152010, 2010.

Perring, A. E., Pusede, S. E., and Cohen, R. C.: An observational perspective on the atmospheric impacts of alkyl and multifunctional nitrates on ozone and secondary organic aerosol, Chem. Rev., 113, 5848-5870, doi:10.1021/cr300520x, 2013.

Roberts, J. M., Osthoff, H. D., Brown, S. S., Ravishankara, A. R., Coffman, D., Quinn, P., and Bates, T.: Laboratory studies of products of $\mathrm{N}_{2} \mathrm{O}_{5}$ uptake on Cl- containing substrates, Geophys. Res. Lett., 36, L20808, doi:10.1029/2009g1040448, 2009.

Rosen, R. S., Wood, E. C., Wooldridge, P. J., Thornton, J. A., Day, D. A., Kuster, W., Williams, E. J., Jobson, B. T., and Cohen, R. C.: Observations of total alkyl nitrates during Texas Air Quality Study 2000: implications for $\mathrm{O}_{3}$ and alkyl nitrate photochemistry, J. Geophys. Res., 109, 15 pp., doi:10.1029/2003jd004227, 2004.

Schnell, R. C., Oltmans, S. J., Neely, R. R., Endres, M. S., Molenar, J. V., and White, A. B.: Rapid photochemical production of 
ozone at high concentrations in a rural site during winter, Nat. Geosci., 2, 120-122, doi:10.1038/ngeo415, 2009.

Thaler, R. D., Mielke, L. H., and Osthoff, H. D.: Quantification of nitryl chloride at part per trillion mixing ratios by thermal dissociation cavity ring-down spectroscopy, Anal. Chem., 83, 2761-2766, doi:10.1021/ac200055z, 2011.

Thornton, J. A., Wooldridge, P. J., and Cohen, R. C.: Atmospheric NO2: In Situ Laser-Induced Fluorescence Detection at Parts Per Trillion Mixing Ratios, Anal. Chem., 72, 528-539, doi:10.1021/ac9908905, 2000.
Wagner, N. L., Dube, W. P., Washenfelder, R. A., Young, C. J., Pollack, I. B., Ryerson, T. B., and Brown, S. S.: Diode laser-based cavity ring-down instrument for $\mathrm{NO}_{3}, \mathrm{~N}_{2} \mathrm{O}_{5}, \mathrm{NO}$, $\mathrm{NO}_{2}$ and $\mathrm{O}_{3}$ from aircraft, Atmos. Meas. Tech., 4, 1227-1240, doi:10.5194/amt-4-1227-2011, 2011. 